\title{
The Degree of Achieving Development Standards Indicators among Kindergarteners from Parents' Point of View
}

\author{
Naser Ibrahim Al-Sharah \\ Al-Balqa Applied University, \\ Irbid University College, Jordan, \\ Faisal Khalif Al-Sharaa \\ Al Balqa Applied University, \\ Al Zarqa University College, Jordan
}

\begin{abstract}
The objective of this study was to uncover the degree of achieving development standards indicators among kindergarteners from parents' point of view. Descriptive- analytical approach was used, where the researcher used a questionnaire to collect data. It contained 2 demographic variables, which are the mother's level of education and the child's ordinal position and it had 67 questions. The study population consisted of a random sample of 100 parents only. The results showed that kindergarteners achieved the development standards of the Jordanian child at a high degree. It also showed that there statistically significant differences at $0.05 \leq \alpha$ of the degree of achieving development standards indicators among kindergarteners from parents' point of view due to the variables of the mother's level of education and the child's ordinal position. The current study recommends going beyond the kindergarten scope and researches on elementary students from across the entire Hashemite Kingdom of Jordan as a follow-up to this research's findings. kindergartens in Amman will benefit from this study and it would motivate kindergartens teachers in Jordan to focus equally on development standards.
\end{abstract}

Keywords: development standards indicators; kindergartens; parents

\section{Introduction}

The first years of child's life are vital in which he or she gains knowledge and it is considered as the foundation of their lifelong education, making this period 'irreplaceable' when it comes to the development of particular skills, which cannot be obtained as easily in the subsequent periods. Thus, early childhood, especially during kindergarten, is justifiably a crucial period for the development of standard skills and behaviors (Wildova \& Kropáčková, 2015). 
The development of a child at an early age is considered the foundation which ensures children would grow healthy and well, making it a vital factor of the goals of sustainable development, and recognizing the formative component of early childhood has increased the emphasis on lowering the risks of poor child development. It is becoming more and more necessary to improve worldwide measures of children who are at risk of poor development, as well as correctly determining challenges, the effectiveness of interferences, progress, and planning for future investments (Lu et al., 2016).

Early childhood development can be referred to as the physical, intellectual, socioemotional, and linguistic development that young children go through before entering primary schools; any defect in any of its aspects would lead to developmental gaps, which can lead to hefty consequences for these children, their families, and their societies altogether (Nadeau \& Hasan, 2016).

As time goes by, more emphasis is put on acquiring these basic development skills, as the quality of early childhood education is starting to be considered as a complex and controversial matter to the point where it has grown to be a crucial interest of early childhood education studies during the previous decades (Fenech, 2011). According to studies, acquiring these skills efficiently and adequately can widely improve a child's overall development and allow them to advance faster (Sylva et al., 2010). Likewise, other studies have shown that allowing the parents to engage in their children's education proved to have a positive effect on their ability to learn and prevent any social problems that might occur. Thus, cooperation between parents and teachers is perceived as a critical part of high-quality early childhood education (Goff et al., 2012; Fonsén \& Vlasov, 2017).

As a result of the importance of the kindergarten stage on the child's future development and personality, children-concerned institutions have established a few development standards that kindergartens must apply and for children to achieve them. Therefore, the researcher finds it necessary to assess the role of these kindergartens in achieving these criteria for mothers, given that they are the most people who follow up with matters related to their children and their level of growth in different areas.

\section{Significant of the Study}

This study is important from practical and theoretical perspectives. The study is the first experimental research in the literature that searches in development standards indicators among kindergarteners by designing a learning environment based on the principles of child development and adaptation to the surrounding environment and good planning to ensure the development of children in various fields. This study can help in activating the standards and achieving the indicators found in the teacher's standards document in the national standards for kindergartens, which make the teachers feel self-confident and carry positive feelings towards their profession and the awareness that the teacher is no longer a carrier of knowledge. Besides, this research can help determine the educational strategies that teachers must use to influence children, especially through the use of modern and up-to-date methods. 


\section{Statement of the Problem}

The challenge for a kindergarten teacher is to provide high-quality educational services for the child in the kindergarten, and the success of the teacher in achieving this goal requires possessing good planning skills through which you can meet the needs of children in line with the individual differences between them, and contribute to discovering their capabilities.

The planning process calls for setting targets in an actionable program. In addition to drawing a clear picture of the future, identifying effective steps to reach this image, organizing times, and choosing priorities. This process relies on an inventory of the available capabilities and resources, studying them, and determining the procedures for using them, to achieve the desired goals during a specific period.

\section{Questions of the Study}

Question 1: 'What is the degree of achieving development standards indicators among kindergarteners from parents' point of view?'

Question 2: 'Are there statistically significant differences at the level of significance $0.05 \geq a$ of the degree of achieving development standards indicators among kindergarteners from parents' point of view due to the variables of mother's level of education and the child's ordinal position?'

\section{Procedural Definitions of the Terms}

Standards Indicators among Kindergarteners: A reference that accompanies the kindergarten work and ensures that it addresses the basic needs of the child in pre-school education (Nadeau \& Hasan, 2016).

Standard: Model rules, reference orders, or conditions by which we judge or measure the behavior of individuals and groups, patterns of thinking, and procedures (Funnell, Brown, Childs, Haas, Hosey, Jensen, ... \& Siminerio, 2008).

Indicators: Methods for measuring the performance aspects of the organization to emphasize the accuracy of achieving the desired goals (Benbenishty \& Astor, 2007).

Kindergarten: A small school for children aged between four and six years old to prepare them for primary education.

\section{Limitations of the Study}

The human limitation presented a major limitation, where the population of the study included mothers whose children attend the second stage of Kindergarten (KG2) in the neighborhoods of East Amman, Jordan only. Besides, the study has faced some challenges while acquiring related literature, as there was a limited amount of research that tackles such variables. The researcher sees a need for calls to investigate and conducted further research on standards Indicators among Kindergarteners. 


\section{Literature Review}

\section{Development Standards}

UNICEF has provided research regarding the development standards during the first 7 years of a person's life that reinforce their importance in early childhood years of any person, in addition to how child development is determined via many aspects related to childcare, protection, and education. Most of these elements affect the progress of the child in every developmental discipline (the physical, the socio-emotional, and the cognitive domains) in a concurrent manner. It has been stressed that it is not sufficient to take care of children alone, just like how it isn't sufficient to just feed or teach them new things. Children require healthy nutrition, care, attention, love, motivation, acceptance, patience, as well as a suitable environment that allows them to develop properly and provides them with the development standards to do so; neglecting any of these conditions in this time and age has long-term consequences (Anghelescu et al., 2010).

\section{Language Development and Literacy}

At the most general level, the term 'literacy' involves an ability or a skill to perform the acquired skills, such as reading, writing, mathematical skills, etc., where reading literacy is generally referred to as a group of skills and abilities that employ written speech as a mean of communication, enjoyment, education, etc. It's not merely meant the ability to read written texts correctly, but it also requires understanding them, and to be able to evaluate them and derive information from it critically, which can be referred to as the functional application of reading and writing) (Wildova \& Kropáčková, 2015).

Literacy consists of speaking, listening, and visual abilities, including viewing, sketching, and critical thinking - it is not only about reading or writing. Furthermore, other literacies, such as technology, (including video games, programs, internet searching, faxing, e-mails, etc.), popular culture (including films, theatres, and art), functional literacy (including roadmaps and timetables), environmental literacy (mostly for native groups) and literacies that don't have anything to do with English have become relevant and essential in the lives of young children nowadays. Thus, Kindergarten programs should base their definition of literacy on these new ones, with the aim to goal to offer the children with the base they require for a prosperous transition to literacy learning throughout their preparatory year (Raban et al., 2009).

In terms of reading literacy, it requires from the person to master, integrate, and apply many abilities and expertise, learning to read is a developmental process; one which almost all children follow the same pattern and the same reading behaviors when they are taught how to read, which go from appreciation and recognition of the printed material to being aware of phonetics and phonemes, up until acoustics and word recognition. On the other hand, foundation skills revolve around reading skills that primary-grade students commonly improve. When these skills and behaviors are developed early, they serve as a basis for later competencies and efficiencies. They can be regarded as constructing blocks that children learn to use to broaden higher-level skills successfully, thus ending up as skillful readers (Brown, 2014). 


\section{Emotional and Social Development}

Social and emotional development can be defined as the developing ability of young children to 'build lasting relationships with his or her parents, other adults, and peers, as well as experiencing, regulating, and expressing emotions in both socially- and culturally-appropriate manners, in addition to discovering his or her surroundings and examining the contexts of family, society, and tradition' (Darling-Churchill \& Lippman, 2016).

Children's emotional and social development throughout their early childhood phase sets the foundation for his or her development throughout middle childhood, adolescence, etc., during which kindergarteners start to (Halle \& Darling-Churchill, 2016):

1. Develop emotional relationships outside the family circle, otherwise known as friendships;

2. Recognize the differences between socially what is considered acceptable behavior and what is not;

3. Endure difficult tasks without being overly annoyed;

4. Be able to pay attention for longer periods;

5. Avert from interrupting others and exhibit delay-of-gratification skills when sharing with others;

6. Recognize and clarify their personal feelings as well as others' feelings;

7. Manage their overflowing emotions in socially-acceptable approaches increasingly; and

8. Solve some social problems on his or her own.

These social and emotional experiences with either parent, caregivers, as well as interactions with peers and other adults at an early stage pave the road for future academic and personal aftermaths and might assist other development areas (Darling-Churchill \& Lippman, 2016).

\section{Motor Development and Physical Health}

Motor skills are one of the few skills that come naturally to a child after their birth. Even though some studies came to say that early infant motions are nothing but ordinarily reflexive, involuntary, and unrelated reflexes, newer studies came to defy this idea, showing that infants perform significant motor activities since their first few minutes after delivery, and most likely even before and that these movements have to affect later development. It has been understood that motor development contributes to the physical growth and healthiness of the child. However, and according to previous studies and research, it is clarified how this occurs to a developing body. For example, recent investigations showed that some motor skills could be enhanced through playing, while others showed how parents, instructors, and caregivers could improve their playtime and bolster its impact on the child's physical development (Trawick-Smith, 2014).

Mastering motor skills is the only way that allows a person - young or old - to explore, experiment, and discover the countless wonders of life around them. Physical activities in early childhood are crucial when it comes to reducing the growing health risks that are related to motor activities, such as obesity. In such a case, the development of the child largely depends on the quality of the 
expressed movements. For example, younger children love to play and move around freely without any limitations or hindrances. However, while they are allowed to move freely, their performance improves drastically in terms of cognitive and emotional domains. The type of freedom offers the children a tangible approach through which they can interact with the world around them (David \& Gbenga, 2014).

Childcare and kindergarten-based interventions aim to enhance children's motor skills, in which they have succeeded, the same as how school-based interventions operate. For example, motor development has been enhanced among first-grade children and preschool by adopting a development-focused program as well as an early-education program; these either included motor skills with other learning skills or focused exclusively on motor development. Single-blinded interventions aimed primarily to enhance motor development and secondarily to reduce the level of obesity and increase physical activities among young children were conducted in childcare centers. That intervention was implemented by teaching educators about the importance of supporting physical activities in children, adapting to the childcare-built environment, and even encouraged educators to get involved with the parents in motor development promotion and daily physical activities (Laukkanen, 2016).

\section{Logical Thinking}

In earlier times, the focus on early childhood education has been limited to acquiring basic literacy, such as reading, writing, and simple mathematics, and didactic teaching was the prominent method of teaching in most kindergartens. However, and in recent years, the early childhood landscape started witnessing several adjustments to start up with a more progressive technique that aimed to develop critical thinking skills among kindergarten children; it, however, came across some difficulty in terms of application within the context of early childhood, and what strategies can be employed to promote critical wondering among children (Tay-Lim, 2011).

Within the context of basic education, logical thinking can be defined as a key cognitive domain that is required for one to succeed in his or her social and academic life, given how it is a requirement for adopting and strengthening the four major language skills speaking, listening, reading, and writing. To acquire and master these skills efficiently, a person needs to adopt both consciousness and deliberative activities, an achievement that is linked to logical thinking. For that reason, it's important to improve logical thinking skills and make it a precondition for kindergarteners to acquire the four language skills and as soon as possible, as well as finding an effective way to do so (Säre et al., 2016).

\section{Previous Studies}

Lembke and Foegen (2009) conducted a study to identify the early numeracy indicators for kindergarten and first-grade students. A descriptive-analytical approach was used. The sample consisted of 72 Kindergarten and first-grade students. The results revealed that three of the four measures examined by the study showed encouraging technical adequacy characteristics when considering the potential of these measures as indicators of student mastery in mathematics that can be applied in both examination and progress monitoring purposes, and 
were consistently less positive than those of other measures. Moreover, the quantitative set scale was less reliable retest test, produced standard validity coefficients that were especially low for kindergarten students, and failed to reflect fundamental changes in student performance from fall to spring.

Pont (2013) conducted a study aimed to identify the features and application of standards in different OECD countries. It focuses on specific approaches adopted in many OECD countries and partner countries and regions and analyses relevant standards and policies in general, these countries include, Brazil, Australia, Canada, England, Chile, Germany, Mexico, Korea, New Zealand, Norway; and the United States, the analytical approach was used. The result showed that the development of newly established standards for teachers and school administrators has become a necessity in all countries. Furthermore, the educational policies' variations, particularly those related to assessment and reporting, occur at a very rapid pace and contribute to the development of students 'skills at a young age.

Tymms, Merrell, Hawker and Nicholson (2014) conducted a study aimed to identify the indicators of performance in primary schools then comparing it to entry to school performance and the progress made in the first year in four jurisdictions and England. A descriptive-analytical approach was used. The population consisted of schools in New Zealand, Scotland, and England. Whereas the sample consisted of 1100 students. The PIPS validity report was defined to produce a national average to tell when the children enter schools what they can do in each country. The results revealed that cognitive scales came high in England for early mathematics, early reading, vocabulary, and phonemic awareness, while results showed that children whose first language is not English had encountered major difficulties at first.

Chang, Lehmann, Winter and Finkbeiner (2018) conducted a study, aimed to analyse the Sustainable Child Development Index (SCDI) for Countries. An analytical approach was used. The sustainable child development index currently addresses education, health, safety, environmental aspects described in 25 indicators, and finally economic status in general. By taking the benchmarks derived from the SDG goals, the results of the 2015 Sustainable Development Index in 138 countries were calculated. The results of the study indicated a significant inequality in the case of sustainable child development. European countries generally enjoy a better position in the sustainable development of children. By contrast, $76 \%$ of Asian countries and $90 \%$ of African countries are classified as countries with medium and low levels.

Wood (2019) conducted a study, aimed to discover the Kindergarten Reading Readiness and Developmental Indicators for the Assessment of Learning. A descriptive-analytical approach was used. The sample consisted of 118 kindergarten students during the academic year 2016-2017. The results revealed that within-group t-tests revealed the group identified as not having a gap increased by $26 \%, \mathrm{t}(26)=-11.47, \mathrm{p}<.001$, while the group identified as having a reading readiness gap increased their average RBI reading performance by $47 \%$. However, the between groups (t-test) comparing the groups' RBI difference scores indicated a closed but still significant gap of 6.8 points remaining, so it was significant, $\mathrm{t}(116)=-3.12, \mathrm{p}=.002$, 


\section{Methodology}

\section{The Population of the Study and its Sample}

The study population comprised of mothers whose children attend the second stage of Kindergarten (KG2) in the neighborhoods of East Amman, taking into consideration that they have finished kindergarten, where one division of 6 kindergartens was selected. A random sample of 100 mothers was selected, who have been classified into the demographic characteristics in Tables 1 and 2 .

Table 1: Mother's Level of Education

\begin{tabular}{|l|c|c|}
\hline \multirow{2}{*}{ Mother's Level of Education } & \multicolumn{2}{|c|}{ Sample } \\
\cline { 2 - 3 } & Percentage $\%$ & Frequency \\
\hline Below High School & $28 \%$ & 28 \\
\hline High School & $20 \%$ & 20 \\
\hline Bachelor's Degree or Higher & $52 \%$ & 52 \\
\hline Total & $\mathbf{1 0 0 . 0}$ & $\mathbf{1 0 0}$ \\
\hline
\end{tabular}

Table 2: Demographic Characteristics of the Study Sample (Child's Ordinal Position

\begin{tabular}{|l|c|c|}
\hline \multirow{2}{*}{ Child's Ordinal Position } & \multicolumn{2}{|c|}{ Sample } \\
\cline { 2 - 3 } & Percentage $\%$ & Frequency \\
\hline First Child & $16 \%$ & 16 \\
\hline Middle Child & $47 \%$ & 47 \\
\hline Last Child & $23 \%$ & 23 \\
\hline Only Child & $14 \%$ & 14 \\
\hline Total & $\mathbf{1 0 0} \%$ & $\mathbf{1 0 0}$ \\
\hline
\end{tabular}

For the mother's level of education, it seems that Below High School received a percentage of $28 \%$, while the percentage of High School was $20 \%$, which is the lowest among the three, and the Bachelor's Degree or higher had a percentage of $52 \%$, which is the highest among the three. For the child's ordinal position, it seems that First child received a percentage of $16 \%$, which is the lowest between the four, while the percentage of Middle child was $47 \%$, which is the highest between the four, the Last child had a percentage of $23 \%$, and finally, the Only child with a percentage of $14 \%$.

\section{Research Instrument}

The instrument questionnaire was prepared based on the development standards of the Jordanian child and its indicators, which are accredited by the Jordanian Ministry of Education. It contained 67 items that measure the degree of achieving development standards indicators among kindergarteners from parents' point of view. The questionnaire has been being distributed to the study sample by hand. The questionnaire contained 2 demographic variables, which are the mother's level of education and the child's ordinal position, and had 67 questions that represent the following study variables:

1. Language Development and Literacy: contains 10 questions.

2. Emotional and Social Development: contains 16 questions.

3. Motor Development and Physical Health: contains 15 questions.

4. Logic and Thinking: contains 26 questions. 
Table 3: Cronbach's Alpha for the Study Domains

\begin{tabular}{|c|l|c|}
\hline $\mathbf{N}$ & Domain & Value of (a) \\
\hline $\mathbf{1}$ & Language Development and Literacy & $\mathbf{0 . 9 3 9}$ \\
\hline $\mathbf{2}$ & Emotional and Social Development & $\mathbf{0 . 8 7 2}$ \\
\hline $\mathbf{3}$ & Motor Development and Physical Health & $\mathbf{0 . 8 7 3}$ \\
\hline $\mathbf{4}$ & Logic and Thinking & $\mathbf{0 . 9 5 0}$ \\
\hline & Total & $\mathbf{0 . 9 7 4}$ \\
\hline
\end{tabular}

Table 3 shows that the total Cronbach's Alpha for the study domains was above 0.60 , which indicates the stability of the results of this study. The researcher used Pearson's correlation coefficient to check the reliability of the study tool. The results revealed that all the study items were stable and positive.

Table 4: Correlations for the Study Domains

\begin{tabular}{|c|l|c|c|}
\hline $\mathbf{N}$ & Domain & Pearson Correlation & Sig \\
\hline $\mathbf{1}$ & Language Development and Literacy & $\mathbf{0 . 9 1 3 ^ { * * }}$ & $\mathbf{. 0 0 0}$ \\
\hline $\mathbf{2}$ & Emotional and Social Development & $\mathbf{0 . 8 7 1 ^ { * * }}$ & $\mathbf{. 0 0 0}$ \\
\hline 3 & $\begin{array}{l}\text { Motor Development and Physical } \\
\text { Health }\end{array}$ & $\mathbf{0 . 8 9 6 ^ { * * }}$ & .000 \\
\hline $\mathbf{4}$ & Logic and Thinking & $\mathbf{0 . 9 6 3 ^ { * * }}$ & .000 \\
\hline ** Correlation is significant at the 0.01 level (2-tailed). \\
\hline
\end{tabular}

\section{The Results of the Study}

Question 1: What is the degree of achieving development standards indicators among kindergarteners from parents' point of view?

Table 5: Descriptive Statistics of the Study Domains

\begin{tabular}{|c|l|c|c|c|}
\hline N & Domain & Mean & Std. Deviation & Level \\
\hline F1 & Language Development and Literacy & 3.85 & 0.92 & High \\
\hline F2 & Emotional and Social Development & 4.06 & 0.49 & High \\
\hline F3 & Motor Development and Physical Health & 4.20 & 0.45 & High \\
\hline F4 & Logic and Thinking & 4.12 & 0.58 & High \\
\hline & Total & $\mathbf{4 . 0 6}$ & $\mathbf{0 . 5 6}$ & High \\
\hline
\end{tabular}

Table 5 shows that the Language Development and Literacy field has reached a mean of 3.85 and standard deviation of 0.92 with a high impact, while the Emotional and Social Development field has reached a mean of 4.06 and a standard deviation of 0.49, also with high impact. Moreover, the Motor Development and Physical Health field has reached a mean of 4.20 and a standard deviation of 0.45 with high impact, while the Logic and Thinking field has reached a mean of 4.12 and a standard deviation of 0.58 with high impact, as the previous fields have.

Question 2: Are there statistically significant differences at the level of significance $(0.05 \geq a)$ of the degree of achieving development standards indicators among kindergarteners from parents' point of view due to the variables of mother's level of education and the child's ordinal position? 


\section{Mother's Level of Education}

To show the differences between the groups, one-way ANOVA was used as shown in Table 6.

Table 6: One-Way ANOVA Test

\begin{tabular}{|c|c|c|c|c|c|c|}
\hline Domain & $\begin{array}{l}\text { Source of } \\
\text { Variance }\end{array}$ & $\begin{array}{l}\text { Sum of } \\
\text { Squares }\end{array}$ & DF & $\begin{array}{l}\text { Mean } \\
\text { Square }\end{array}$ & $\mathbf{F}$ & Sig. \\
\hline \multirow{3}{*}{$\begin{array}{l}\text { Language } \\
\text { Development and } \\
\text { Literacy }\end{array}$} & Between Groups & 29.448 & 2 & 14.724 & \multirow{3}{*}{25.873} & \multirow{3}{*}{.000} \\
\hline & Within Groups & 55.202 & 97 & .569 & & \\
\hline & Total & 84.650 & 99 & & & \\
\hline \multirow{3}{*}{$\begin{array}{l}\text { Emotional and Social } \\
\text { Development }\end{array}$} & Between Groups & 2.593 & 2 & 1.297 & \multirow{3}{*}{5.945} & \multirow{3}{*}{.004} \\
\hline & Within Groups & 21.157 & 97 & .218 & & \\
\hline & Total & 23.750 & 99 & & & \\
\hline \multirow{3}{*}{$\begin{array}{l}\text { Motor Development } \\
\text { and Physical Health }\end{array}$} & Between Groups & 2.897 & 2 & 1.448 & \multirow{3}{*}{8.130} & \multirow{3}{*}{.001} \\
\hline & Within Groups & 17.281 & 97 & .178 & & \\
\hline & Total & 20.178 & 99 & & & \\
\hline \multirow{3}{*}{ Logic and Thinking } & Between Groups & 5.016 & 2 & 2.508 & \multirow{3}{*}{8.575} & \multirow{3}{*}{.000} \\
\hline & Within Groups & 28.370 & 97 & 292 & & \\
\hline & Total & 33.386 & 99 & & & \\
\hline
\end{tabular}

Table 6 shows that there is a significant impact due to the mother's level of education and that the level of significance for all fields was less than 0.05.

Table 7: Scheffé's Test

\begin{tabular}{|c|c|c|c|c|c|}
\hline Field & Categories & Mean & $\begin{array}{l}\text { Below } \\
\text { High } \\
\text { School }\end{array}$ & $\begin{array}{l}\text { High } \\
\text { School }\end{array}$ & $\begin{array}{c}\text { Bachelor's } \\
\text { Degree or } \\
\text { Higher }\end{array}$ \\
\hline \multirow{3}{*}{$\begin{array}{l}\text { Language } \\
\text { Development } \\
\text { and Literacy }\end{array}$} & Below High School & 3.17 & & & \\
\hline & High School & 3.48 & .30714 & & \\
\hline & $\begin{array}{l}\text { Bachelor's Degree or } \\
\text { Higher }\end{array}$ & 4.36 & $1.19368^{*}$ & $.88654^{*}$ & \\
\hline \multirow{3}{*}{$\begin{array}{l}\text { Emotional and } \\
\text { Social } \\
\text { Development }\end{array}$} & Below High School & 3.81 & & & \\
\hline & High School & 4.11 & .30134 & & \\
\hline & $\begin{array}{l}\text { Bachelor's Degree or } \\
\text { Higher }\end{array}$ & 4.18 & $.37345^{*}$ & .07212 & \\
\hline \multirow{3}{*}{$\begin{array}{l}\text { Motor } \\
\text { Development } \\
\text { and Physical } \\
\text { Health }\end{array}$} & Below High School & 4.04 & & & \\
\hline & High School & 4.00 & .04619 & & \\
\hline & $\begin{array}{l}\text { Bachelor's Degree or } \\
\text { Higher }\end{array}$ & 4.36 & $.31996^{*}$ & $.36615^{*}$ & \\
\hline \multirow{3}{*}{$\begin{array}{l}\text { Logic and } \\
\text { Thinking }\end{array}$} & Below High School & 3.83 & & & \\
\hline & High School & 3.99 & .16291 & & \\
\hline & $\begin{array}{l}\text { Bachelor's Degree or } \\
\text { Higher }\end{array}$ & 4.33 & $.50211^{*}$ & .33920 & \\
\hline
\end{tabular}

Table 7 shows that the differences were in favor of the Bachelor's Degree or higher in all fields.

\section{The Child's Ordinal Position}

To show the differences between the groups, one-way ANOVA was used as shown in Table 8. 
Table 8: One-Way ANOVA Test

\begin{tabular}{|c|c|c|c|c|c|c|}
\hline Field & $\begin{array}{l}\text { Source of } \\
\text { Variance }\end{array}$ & $\begin{array}{l}\text { Sum of } \\
\text { Squares }\end{array}$ & DF & $\begin{array}{l}\text { Mean } \\
\text { Square }\end{array}$ & $\mathbf{F}$ & Sig. \\
\hline \multirow{3}{*}{$\begin{array}{l}\text { Language Development } \\
\text { and Literacy }\end{array}$} & Between Groups & 14.843 & 3 & 4.948 & \multirow{3}{*}{6.804} & \multirow{3}{*}{.000} \\
\hline & Within Groups & 69.807 & 96 & .727 & & \\
\hline & Total & 84.650 & 99 & & & \\
\hline \multirow{3}{*}{$\begin{array}{l}\text { Emotional and Social } \\
\text { Development }\end{array}$} & Between Groups & .026 & 3 & .009 & \multirow{3}{*}{.035} & \multirow{3}{*}{.991} \\
\hline & Within Groups & 23.724 & 96 & .247 & & \\
\hline & Total & 23.750 & 99 & & & \\
\hline \multirow{3}{*}{$\begin{array}{l}\text { Motor Development } \\
\text { and Physical Health }\end{array}$} & Between Groups & 2.326 & 3 & .775 & \multirow{3}{*}{4.170} & \multirow{3}{*}{.008} \\
\hline & Within Groups & 17.852 & 96 & .186 & & \\
\hline & Total & 20.178 & 99 & & & \\
\hline \multirow{3}{*}{ Logic and Thinking } & Between Groups & 3.042 & 3 & 1.014 & \multirow{3}{*}{3.208} & \multirow{3}{*}{.027} \\
\hline & Within Groups & 30.344 & 96 & .316 & & \\
\hline & Total & 33.386 & 99 & & & \\
\hline
\end{tabular}

Table 8 illustrates that there is a significant impact due to the child's ordinal position and that the level of significance for all fields was less than 0.05 , except for the Emotional and Social Development field, which was more than 0.05.

Table 9: Scheffé's Test

\begin{tabular}{|c|c|c|c|c|c|c|}
\hline Field & Categories & Mean & $\begin{array}{l}\text { First } \\
\text { Child }\end{array}$ & $\begin{array}{l}\text { Middle } \\
\text { Child }\end{array}$ & $\begin{array}{c}\text { Last } \\
\text { Child }\end{array}$ & $\begin{array}{l}\text { Only } \\
\text { Child }\end{array}$ \\
\hline \multirow{4}{*}{$\begin{array}{l}\text { Language } \\
\text { Development and } \\
\text { Literacy }\end{array}$} & First Child & 4.44 & & & & \\
\hline & Middle Child & 3.64 & $.79495^{*}$ & & & \\
\hline & Last Child & 3.51 & $.92446^{*}$ & .12951 & & \\
\hline & Only Child & 4.43 & .00893 & $.78602^{*}$ & $.91553^{*}$ & \\
\hline \multirow{4}{*}{$\begin{array}{l}\text { Motor Development } \\
\text { and Physical Health }\end{array}$} & First Child & 4.44 & & & & \\
\hline & Middle Child & 4.14 & .29982 & & & \\
\hline & Last Child & 4.03 & $.41268^{*}$ & .11286 & & \\
\hline & Only Child & 4.40 & .04167 & -.25816 & .37101 & \\
\hline \multirow{4}{*}{ Logic and Thinking } & First Child & 4.38 & & & & \\
\hline & Middle Child & 3.99 & $.38958^{*}$ & & & \\
\hline & Last Child & 4.03 & .35044 & .03914 & & \\
\hline & Only Child & 4.39 & .00515 & .39473 & $.35559^{*}$ & \\
\hline
\end{tabular}

Table 9 shows that the differences were in favor of the (First Child) in the fields of Language Development and Literacy, Motor Development and Physical Health, as well as in favor of the Only Child in the field of Logic and Thinking.

\section{Discussion of the Results}

Question 1: What is the degree of achieving development standards indicators among kindergarteners from parents' point of view?

Table 5 shows that the achieving development standards among kindergarteners is high and has a mean of 4.06 and a standard deviation that amounts to 0.56 , where none of the fields got a low degree. Moreover, it also shows that the Language Development and Literacy field scored last and has displayed a high 
impact, where it is mean reached 3.85 with a standard deviation of 0.92 . This could be attributed to the fact that kindergartens teachers put more focus on teaching language and literacy-related subjects to kindergarteners to set the foundation for more advanced language requirements at later stages. The overall result of this question can be attributed to several factors, such as the necessity of kindergarten teachers to have a Bachelor's degree in child education at a minimum; also, this study was performed in the capital city of Amman, which means kindergartens are fully equipped in terms of buildings, tools, and means; also, that most teachers are subjected to in-service training courses.

This result agreed with Bassok et al. (2016), who showed that literacy in kindergartens has witnessed a substantial increase and started to use textbooks, practicing words by dictation to improve spelling, writing short stories and reports, and using workbooks and worksheets.

On the other hand, the Logic and Thinking field scored last, still with a high impact, where the mean reached 4.12 and the standard deviation was at 0.58 . This could be since the fact that the kindergarten teacher preparation programs include special courses in the development of children's thinking as well as the various in-class and extracurricular activities, that is in addition to the adoption of the teaching staff method in the daily kindergarten program and the adoption of an interactive national curriculum and the teacher's guide that has been prepared by experts and university professors.

The result of this study also agreed with Daniel and Gagnon (2011), who showed that logical thinking among kindergarteners was characterized as simply-stated points of views, somewhat generalized and unjustified statements, and sometimes kindergarteners are unable to materialize a logical statement or it would contain a false or a circular justification.

Question 2: Are there statistically significant differences at the level of significance $(0.05 \geq \alpha)$ of the degree of achieving development standards indicators among kindergarteners from parents' point of view due to the variables of mother's level of education and the child's ordinal position?

It is shown from the results in the Table 6 that there is a significant impact of the degree of achieving development standards indicators among kindergarteners from parents' point of view due to the mother's level of education, where the level of significance was less than 0.05. It is also shown in Table 7 that the significant differences were in favor of Bachelor's Degree or higher in all fields Language Development and Literacy, Emotional and Social Development, Motor Development and Physical Health, Logic and Thinking. This could be because parents with higher degrees take better care of their children and pay more attention to the development standards that their children need to obtain to become efficient in their lives later on than parents with lower degrees do. It could be also mean that parents have high awareness regarding the importance of this stage and how crucial it is to take care of it; it also implies that the level of awareness is directly proportional to the level of education. This result is consistent with the result of the study of Steinmayr et al. (2010), which showed a positive association between parents' education and children's academic achievement. 
On the other hand, it has been shown from the results in Table 8 that there is a significant impact of the degree of achieving development standards indicators among kindergarteners from parents' point of view due to the child's ordinal position, where the level of significance was less than 0.05, except the (Emotional and Social Development) field, which was higher than 0.05. This could be attributed to the fact that parents have more time and resources to care for the only child and/or the first one, and are more enthusiastic about educating and attending to the first child in comparison to his or her siblings; as such, the child's ability to acquire aspects such as language, motor, and physical health, as well as logic and thinking are affected when and if parents differentiate between their children, favoring, for example, the elder son over his or her siblings.

It is also shown in Table 9 that these significant differences were in favor of First Child in three out of the four fields Language Development and Literacy, Motor Development and Physical Health, Logic and Thinking. This could be because parents focus their attention more on the first child, given that he or she is their firstborn, and is more special to them.

\section{Conclusion}

The importance of achieving development standards indicators among kindergarteners has been receiving even more attention from different parties as the days go by, especially in the primary educational institutions in general, and kindergartens in specific, as they are considered to be the most fundamental institutions in any society due to their vital role in educating the young offspring and providing them with necessary skills that will serve as a solid base on which their entire educational journey will rely on. Thus, many studies have shed light on the matter of development standards, while many kindergartens have started to focus on these standards more by applying the necessary adjustments. This study tried to uncover the degree of human achieving development standards indicators among kindergarteners from parents' point of view. In light of the study results, it has been concluded that kindergartens are taking a more serious approach toward teaching development standards, given how all fields had high impacts; however, there could be room for improvement. In this retrospect, kindergartens and other responsible parties should implement the development standards in kindergartens' curriculum by making the appropriate adjustments to the curriculum and hiring adequate teachers who can apply them effectively, while taking into consideration each child's ability, thus improving the quality of kindergarten education and the acquisition of development standards tremendously.

\section{Research Limitations and Direction for Further Research}

Many limitations must be put into consideration; such as insincerity and conflict when the members of the study sample answer the questionnaire, some of which are excluded by the researcher, then comes the human limitation, where the population of the study was limited to include parents of kindergarteners in Jordan only. The second limitation would be. The third limitation was the lack 
of resources to work with, as the topic of development standards indicators among kindergarteners was not widely addressed.

The current study recommends going beyond the kindergarten scope and researches on elementary students from across the entire Hashemite Kingdom of Jordan as a follow-up to this research's findings. Further qualitative research would be needed in the future to accurately assert the degree of achieving development standards indicators among kindergarteners.

Further research into the broader degree of achieving development standards indicators among kindergarteners as well as new outcomes, whether they are positive or negative, would be highly appreciated by the researcher.

\section{References}

Anghelescu, A., Boca, C., Hersey, I., Popescu, C., Sativa, E., Ulrich, C., Novak, C., \& Ionescu, M. (2010). Early Learning and Development Standards for Children from Birth to 7 Years Old. The Report, UNICEF Romania, București.

Bassok, D., Latham, S., \& Rorem, A. (2016). Is Kindergarten the New First Grade? AERA Open, 1(4), 1-31. https:// doi.org/10.1177/2332858415616358

Benbenishty, R., \& Astor, R. (2007). Monitoring indicators of children's victimization in school: Linking national-, regional-, and site-level indicators. Social Indicators Research, 84(3), 333-348. https://doi.org/10.1007/s11205-007-9116-4

Brown, C. (2014). Language and Literacy Development in the Early Years: Foundational Skills that Support Emergent Readers. Language and Literacy Spectrum, 24(1), 3549.

Chang, Y., Lehmann, A., Winter, L., \& Finkbeiner, M. (2018). The Sustainable Child Development Index (SCDI) for Countries. Sustainability, 10(5), 1563. https://doi.org/10.3390/su10051563

Daniel, M., \& Gagnon, M. (2011). Developmental Process of Dialogical Critical Thinking in Groups of Pupils Aged 4 to 12 Years. Creative Education, 2(5), 418-428. https://doi.org/10.4236/ce.2011.25061

Darling-Churchill, K., \& Lippman, L. (2016). Early Childhood Social and Emotional Development: Advancing the Field of Measurement. Journal of Applied Developmental Psychology, 45(1), 1-7. https:// doi.org/10.1016/j.appdev.2016.02.002

David, B., \& Gbenga, J. (2014). Role of Physical Activity and Motor Learning in Child Development. Journal of Nigeria Association of Sports Science and Medicine, 15(1), 239-247.

Fenech, M. (2011). An Analysis of the Conceptualisation of 'Quality' in Early Childhood Education and Care Empirical Research: Promoting 'Blind Spots' as Foci for Future Research. Contemporary Issues in Early Childhood, 12(2), 102-117. https://doi.org/10.2304/ciec.2011.12.2.102

Fonsén, E., \& Vlasov, J. (2017). Leading Pedagogical Quality in the Context of Finnish Child Care. In Charlotte Ringsmose and Grethe Kragh-Müller (eds.), Nordic Social Pedagogical Approach to Early Years, 15(1), 253-265. Springer, Cham. https://doi.org/10.1007/978-3-319-42557-3_15

Funnell, M., Brown, T., Childs, B., Haas, L., Hosey, G., Jensen, B., \& Siminerio, L. (2008). National standards for diabetes self-management education. Diabetes care, 31(1), 97-104. https://doi.org/10.2337/dc08-s097

Goff, J., Evangelou, M., \& Sylva, K. (2012). Enhancing Parents' Ways of Supporting their 
Children's Early Learning through Participation in an Early-Intervention Project in the UK: The Early Learning Partnership Project. Journal of Family Research, 24(2), $160-177$.

Halle, T., \& Darling-Churchill, K. (2016). Review of Measures of Social and Emotional Development. Journal of Applied Developmental Psychology,45(1), 8-18. https:// doi.org/10.1016/j.appdev.2016.02.003

Laukkanen, A. (2016). Physical Activity and Motor Competence in 4-8-Year Old Children: Results of a Family-Based Cluster-Randomized Controlled Physical Activity Trial. Studies in Sport, Physical Education and Health, (238).

Lembke, E., \& Foegen, A. (2009). Identifying early numeracy indicators for kindergarten and first-grade students. Learning Disabilities Research \& Practice, 24(1), 12-20. https://doi.org/10.1111/j.1540-5826.2008.01273.x

Lu, C., Black, M., \& Richter, L. (2016). Risk of Poor Development in Young Children in Low-Income and Middle-Income Countries: An Estimation and Analysis at the Global, Regional, and Country Level. The Lancet Global Health, 4(12), 916-922. https://doi.org/10.1016/s2214-109x(16)30266-2

Nadeau, S., \& Hasan, R. (2016). Early Childhood Development: A Review of the Global Evidence. Policy Brief, World Bank Group, Washington, D.C. https://doi.org/10.1596/24575

Pont, B. (2013). Learning standards, teaching standards, and standards for school principals: A comparative study. OECD Education Working Papers, No. 99, OECD Publishing, Paris. https://doi.org/10.1787/5k3tsjqtp90v-en

Raban, B., Brown, P., Care, E., Rickards, F., \& O'Connell, T. (2009). Young Learners: Learning and Literacy in the Early Years. Paper presented at the AARE Annual Conference, Canberra.

Säre, E., Luik, P., \& Tulviste, T. (2016). Improving Pre-Schoolers' Reasoning Skills Using the Philosophy for Children Programme. Trames: A Journal of the Humanities and Social Sciences, 20(3), 273-295. https://doi.org/10.3176/tr.2016.3.03

Steinmayr, R., Dinger, F., \& Spinath, B. (2010). Parents' Education and Children's Achievement: The Role of Personality. European Journal of Personality, 24(6), 535550. https://doi.org/10.1002/per.755

Sylva, K., Melhuish, E., Sammons, P., Siraj-Blatchford, I., \& Taggart, B. eds., (2010). Early Childhood Matters: Evidence from the Effective Pre-School and Primary Education Project. Routledge, London. https:/ / doi.org/10.4324/9780203862063

Tay-Lim, J. K. H. (2011). Developing Young Children's Critical Thinking Skills through Conversations. Paper Presented at the ERAS Conference, National Institute of Education, Jurong West, 8-9 September 2011.

Trawick-Smith, J. (2014). The Physical Play and Motor Development of Young Children: A Review of Literature and Implications for Practice. Center for Early Childhood Education, Eastern Connecticut State University.

Tymms, P., Merrell, C., Hawker, D., \& Nicholson, F. (2014). Performance indicators in primary schools: A comparison of performance on entry to school and the progress made in the first year in England and four other jurisdictions. Research Report, Department of Education, CEM Centre, Durham University.

Wildova, R., \& Kropáčková, J. (2015). Early Childhood Pre-Reading Literacy Development. Procedia-Social and Behavioral Sciences, 191(1), 878-883. https://doi.org/10.1016/j.sbspro.2015.04.418

Wood, T. (2019). Kindergarten Reading Readiness and Developmental Indicators for the Assessment of Learning. Doctoral Dissertation, Walden University. 